\title{
GENETIC CONTROL AND GENOTYPE-BY-ENVIRONMENT INTERACTION OF WOOD WEIGHT IN Eucalyptus CLONES IN THE STATE OF RIO GRANDE DO SUL, BRAZIL ${ }^{1}$
}

\author{
Gleison Augusto Santos², Andrei Caíque Pires Nunes ${ }^{3 *}$, Marcos Deon Vilela Resende ${ }^{4}$, Luciana Duque \\ Silva $^{5}$, Antonio Higa ${ }^{6}$ and Teotônio Francisco Assis ${ }^{7}$
}

\footnotetext{
${ }^{1}$ Received on 06.03.2015 accepted for publication on 02.09.2016.

${ }^{2}$ Universidade Federal de Viçosa, Departamento de Engenharia Florestal, Viçosa, MG - Brasil. E-mail: <gleisons.ufv@gmail.com>.

${ }^{3}$ Universidade Federal de Viçosa, Programa de Pós-graduação em genética e melhoramento, Viçosa, MG - Brasil. E-mail: $<$ andreicaique@yahoo.com.br>.

${ }^{4}$ Empresa Brasileira de Pesquisa Agropecuária, Centro Nacional de Pesquisa de Florestas, Colombo, PR - Brasil. E-mail: $<$ marcos.deon@gmail.com>.

${ }^{5}$ Universidade de São Paulo, Campus Luiz de Queiroz, Piracicaba, SP - Brasil. E-mail: <lucianaduques@yahoo.com.br>.

${ }^{6}$ Universidade Federal do Paraná, Setor de Ciências Agrárias, Departamento de Ciências Florestais, Curitiba, PR - Brasil. E-mail: <antonio.higa@gmail.com>.

${ }^{7}$ Assistech Tecnologia em Melhoramento, Nova Lima, MG - Brasil. E-mail: <assisteo@terra.com.br>.

* Corresponding author.
}

\begin{abstract}
The present study aimed to evaluate the genetic control and genotype-by-environment interaction in wood weight of Eucalyptus clones in four environments located in the state of Rio Grande do Sul, Brazil, aiming to select superior genotypes. In 2007, a network of clonal tests was established with 864 clones of Eucalyptus. At three years of age, diameter at breast height and total height were measured, as was depth of Pilodyn penetration, for indirect inference of wood basic density. The mean annual increment of dry weight (MAIweight) was calculated. Individual heritability of 0.148 and of 0.48 was found for MAIweight and Pilodyn penetration depth, respectively. The genetic correlation between environments ranged from 0.503 to 0.926 for all traits. The genotype-by-environment interaction was significant for the MAIweight index (0.533). From the environment interaction analysis, 3 "improvement areas" were defined for the trait MAIweight. The grouping of the traits wood density and volume to create a wood weight index was essential for a more accurate selection, since there was a change of $37 \%$ compared to the ranking of clones for volume. The simultaneous selection for stability and adaptability provided higher gains when compared to selection based on predicted genotypic values between environments. Moreover, MHPRVG allowed an increase in gains compared to the control. Thus, the five best clones were selected based on these criteria: 39912 (E. urophylla), 39659 (E. urophylla), 6808 (E. grandis), 36190 (E. saligna), 39407 (E. grandis x E. urophylla).
\end{abstract}

Keywords: Adaptability; Stability; Genetic improvement.

\section{CONTROLE GENÉTICO E INTERAÇÃO GENÓTIPO X AMBIENTE DO PESO DE MADEIRA EM CLONES DE EucalyptuS NO ESTADO DO RIO GRANDE DO SUL}

\begin{abstract}
RESUMO-O presente trabalho objetivou estudar o controle genético e a interação genótipos por ambientes do peso de madeira de clones de Eucalyptus em quatro ambientes do estado do Rio Grande do Sul. No ano de 2007, foi implantada uma rede de testes clonais com 864 clones de Eucalyptus. Aos três anos de idade, foram mensurados o diâmetro a altura do peito, a altura total das árvores e a profundidade de penetração do Pilodyn, para determinação indireta da densidade básica da madeira. O incremento médio anual em peso seco (IMApeso) foi calculado. Herdabilidades individuais de 0,148 para IMApeso e 0,48 para profundidade de penetração do Pilodyn foram constatadas. A correlação genética entre os ambientes variou de 0,503 a 0,926 para as características avaliadas. A interação genótipo x ambiente foi significativa para IMApeso $(0,533)$. A partir da análise de interação dos ambientes, 3 zonas de melhoramento foram definidas para o caráter IMApeso.
\end{abstract}




\begin{abstract}
A junção do caráter densidade básica e volume para a criação de um indice de peso de madeira foi fundamental para exercer uma seleção mais acurada, visto que houve mudança de $37 \%$ no ordenamento dos clones para o caráter volume. A seleção simultânea por estabilidade e adaptabilidade proporcionou ganhos superiores. em relação à testemunha comercial, quando comparada à seleção com base nos valores genotípicos preditos. Dessa forma, os 5 clones superiores foram selecionados com base nesses critérios: 39912 (E. urophylla), 39659 (E. urophylla), 6808 (E. grandis), 36190 (E. saligna), 39407 (E. grandis $x$ E. urophylla)
\end{abstract}

Palavras-chave: Adaptabilidade; Estabilidade, Melhoramento genético.

\section{INTRODUCTION}

Studies on the genotype-by-environment interaction ( G x E) involving adaptability and stability analyses are considered essential for Eucalyptus genetic improvement programs because they allow a detailed evaluation of the interaction between different genetic materials in the diverse environments to which they are subjected in the experimental network (JUNIOR et al., 2006). Estimations of the magnitude and nature of the G $x$ E interaction, as well as the analysis of the genetic control of the trait being investigated, allow the adoption of the best strategy for selecting genetic materials (NARAYANAN et al., 2002; RESENDE, 2002).

Several authors have reported G x E interaction studies in progenies (LAVORANTI et al., 2002; JUNIOR et al., 2006) and clones of Eucalyptus (NUNES et al., 2002; ROCHA et al., 2005; ROSADO et al., 2012; SANTOS et al., 2013; REIS et al., 2014). Despite the relevance of these studies, no study has been carried out with the purpose of analyzing traits related to wood weight. In general, research on the $\mathrm{G} x \mathrm{E}$ interaction in Brazil for selection of superior genotypes has focused only on criteria related to tree growth (SILVA, 2008). This may be due to higher costs and longer periods of time that analyses of physical, chemical and anatomical traits of wood require, making this type of research unfeasible (GOMIDE et al., 2010).

However, several researchers have recommended that wood quality analyses, in line with the criteria for productivity per hectare, should be taken into consideration in research of the $\mathrm{G} x \mathrm{E}$ interaction and in Eucalyptus genetic improvement programs (CAIXETA et al., 2003; GOMIDE et al., 2010; PROTÁSIO et al., 2014). According to Gomide et al. (2010), technological analyses are essential for the establishment of wood quality and selection of genetic materials, targeting high performance in the production of cellulosic pulp. Among the physical traits of wood, basic density has been considered the universal index for evaluating wood quality (CAIXETA et al., 2003; QUEIROZ et al., 2004; GOMIDE et al., 2010). However, like other technological studies, determination of this trait has been neglected due to its high cost, time required for analysis and the need for felling.

In addition to the methods traditionally employed to estimate basic wood density, the Pilodyn method has been used for estimation and/or indirect measurement of this important technological trait in Eucalyptus (GREAVES et al., 1996; MUNERI; RAYMOND, 2000; GOUVÊA et al., 2011; COUTO et al., 2013). This method measures the resistance to penetration in the trunk of the tree to a rigid pin under constant pressure, where the penetration depth is inversely proportional to the density of the wood (GREAVES et al., 1996). This technique allows indirect access to basic wood density quickly, reliably and cost-effectively, without the need to fell trees (GREAVES et al., 1996).

An accurate selection of multispecies Eucalyptus clones based on adaptability, stability and MAIweight index requires a method that produces reliable results and allows selection of genotypes with high yield in different environments. For this purpose, selection can be performed simultaneously, in the context of mixed models, by the method of Harmonic Mean of the Relative Performance of Predicted Genetic Values (MHPRVG), proposed by Resende (2004). Despite successful application of this method in several studies of G x E interaction in Eucalyptus (JÚNIOR et al., 2006; ROSADO et al., 2012; SANTOS et al., 2013), this approach has not yet been reported in studies using wood weight.

Within this context, the present study aimed to evaluate the genetic control and the $\mathrm{G} \times \mathrm{E}$ interaction in wood weight by the method of MHPRVG from different Eucalyptus clones in four environments of the State of Rio Grande do Sul, in order to select superior genotypes for the different environments. 


\section{MATERIALAND METHODS}

\subsection{Experimental Areas}

The experiments were conducted in areas belonging to the company CMPC Celulose Riograndense, in the municipalities of Minas do Leão (forest garden Cambará, lat $30^{\circ} 11^{\prime} \mathrm{S}$, long $52^{\circ} 00^{\circ} \mathrm{W}$ and $141 \mathrm{~m}$ alt), Encruzilhada do Sul (forest garden Capivara, lat $30^{\circ} 27^{\prime} \mathrm{S}$, long $52^{\circ} 39^{\circ} \mathrm{W}$ and $250 \mathrm{~m}$ alt), Dom Feliciano (forest garden Fortaleza $30^{\circ} 29^{\prime} \mathrm{S}$, long $52^{\circ} 19^{\prime} \mathrm{W}$ and alt $378 \mathrm{~m}$ ) and Vila Nova do Sul (forest garden São João, lat $30^{\circ}$ $14^{\prime} \mathrm{S}$, long $53^{\circ} 49^{\prime} \mathrm{W}$ and alt $301 \mathrm{~m}$ ), all located in the State of Rio Grande do Sul. The trees were planted using a spacing of $3.5 \times 2.6$, and the edaphoclimatic data of each site studied can be found in the study of Santos et al. (2013).

\subsection{Data Collection}

At the age of three, the diameter at breast height $(\mathrm{DBH})$ and total height $(\mathrm{Ht})$ of the trees were measured. DBH was measured using a Diametric tape and height was measured using a relascope.

Volume without bark was calculated using the model of Leite et al. (1995), as shown below:

$$
\begin{aligned}
\mathrm{V}=0.000048 * \text { dbh }^{1.720483 *} \text { height }^{1.180736 *} \mathrm{e}^{(-3.00555) *(\mathrm{t} /} \\
\text { dap) } *\left\{1-(\mathrm{d} / \text { dap })^{1+0.228531 * \mathrm{~d}}\right\}+\mathrm{C}
\end{aligned}
$$

$$
R^{2}=99.36
$$

where: DBH: diameter at 1.3 meters in height; height: total height; $\mathrm{tx}=0$, for volume with bark 1 for volume without bark; d: superior commercial diameter; = experimental error.

The Pilodyn method was used for indirect determination of basic density, which consisted of penetration of a steel pin with $2.5 \mathrm{~mm}$ in diameter into the outer surface of the trunk, driven by a spring with a constant force of 6 joules (GREAVES et al., 1996). To this end, it was necessary to strip a rectangular section of the trunk of approximately $3 \mathrm{~cm}$ long and $2 \mathrm{~cm}$ wide at the height of $1.3 \mathrm{~m}$ above the ground (DBH), so that the steel needle pierced only the wood of the tree. After placing the device on the trunk, the trigger was pulled and the penetration into the wood was measured in $\mathrm{mm}$, using a numerical display on the device. The Pilodyn method was used twice, on the North and South sides of the tree. In the case of divergent results, a third test was performed and the divergent number was discarded. For analytical purposes, the number considered was the mean of the two results.

\subsection{MAI weight index}

An index of dry matter (MAI weight) was developed, with the aim of creating a ranking that combines productivity in the field (volume in $\mathrm{m}^{3} /$ ha.year) and wood density (measured indirectly by Pilodyn penetration depth). The index combining the two traits and their respective standard deviations was determined using the formula:

$$
M A I_{\text {weight }}=\left(\frac{V o l_{s c}}{S_{V_{\text {ol }}}}\right) \times\left(\frac{V o l_{X_{t}}}{X_{t}}\right)
$$

$M A I_{\text {weight }}=$ Mean annual increment in wood weight; $V o l_{s c}=$ Volume without bark; $S_{v o l}=$ Standard deviation for the variable volume without bark; $S_{x t}=$ Standard deviation for the variable Pilodyn penetration depth; $X_{t}=$ Pilodyn penetration depth at 1.3 meters of height (DBH).

Thus, equal relative economic weights were assigned to the two traits (volume and Pilodyn penetration depth).

\subsection{Statistical design and analysis of stability and adaptability}

A network of clonal tests with 864 clones of Eucalyptus was implanted in the year 2007, in four environments in the State of Rio Grande do Sul. The main commercial clone utilized by the company was employed as a witness (clone 32864). In each location, the experiment was set up as a randomized block design, with single-tree plots and 30 replicates. The statistical model for analysis of this experimental network in multiple environments, considering the observation per plot, is given by: $y=X b+Z g+$ $W g e+e$, where: $y, b, g$, ge and $e$ are vectors of data, of fixed-effects (mean of blocks by locations), of genotypic effects (random), G x E interaction effects (random) and random errors, respectively. $X, Z$ and $W$ are incidence matrices for $b, g$ and $g e$, respectively (RESENDE, 2002).

The joint selection by MAIweight index and stability and adaptability of genetic materials was based on statistics called Harmonic Mean of the

Revista Árvore, Viçosa-MG, v.40, n.5, p.867-876, 2016

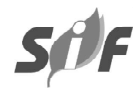


Relative Performance of Predicted Genetic Values (MHPRVG), as described by Resende (2002). All analyses were performed using Selegen-Reml/Blup software. With the predicted genetic values, a joint correlation was obtained between the environments and the pairwise correlation between locations.

\section{RESULTS}

\subsection{Genetic and Statistical Analyses}

Genetic parameters for the traits volume, Pilodyn depth and MAIweight were estimated (Table 1). Individual heritability ranged from 0.147 for volume to 0.48 for Pilodyn penetration depth. The values of accuracy were high (above 0.80 ) for all traits evaluated and genotypic correlation between the environments was high only for the trait Pilodyn penetration depth.

\subsection{Pairwise Genetic Correlations of environments}

The pairwise genetic correlations of environments for the trait MAIweight were: Cambará and Capivara (0.47); Cambará and Fortaleza (0.67); Cambará and São João (0.63); Capivara and Fortaleza (0.33); Capivara and São João (0.52); Fortaleza and São João (0.51).

\subsection{Selection gains in the joint analysis free from the effect of the $\mathbf{G} \times \mathbf{E}$ interaction}

A ranking of the 10 best clones for joint selection among the four environments was carried out for MAIweight (Table 2). Selection gains from the best clones in relation to the breeding population were high, however the gains related to the commercial witness were relatively lower than those obtained in relation to the population.

\subsection{Wood quality aggregation in the selection of superior genotypes}

A coincidence ranking of the 30 best clones for productivity in MAIweight and in volume $\left(\mathrm{m}^{3} /\right.$ ha.year) was performed (Table 3 ). The coincidence between the 30 best for volume and MAIweight was $37 \%$. This demonstrates the importance of adding traits related to wood quality in the selection of superior genetic materials, as the ranking differs from that given when considering only productivity traits.

\subsection{Stability and adaptability}

The results for stability (MHVG), adaptability (PRVG) and stability, adaptability and productivity simultaneously (MHPRVG*MG) for the trait productivity in MAIweight are shown in Table 4. The MHPRVG*MG criterion considers the stability of the genetic material and its adaptability, while also capitalizing on mean productivity of each genotype in all environments evaluated.

\section{DISCUSSIONS}

\subsection{Genetic and Statistical Analyses}

The CVgivalues (\%) (Table 1) found for the traits Pilodyn depth and MAIweight were expressive, with $11.795 \%$ and $19.218 \%$, respectively, of the general mean being due to genotypic variation of these traits. With

Table 1 - Estimates for genetic parameters (REML individual), for volume ( $\mathrm{m}^{3} /$ ha.year), Pilodyn penetration depth and MAIweight for Eucalyptus clones evaluated in the joint analysis between environments.

Tabela 1 - Estimativas de parâmetros genéticos (REML individual), para os caracteres, volume ( $\mathrm{m}^{3} /$ ha.ano), profundidade de penetração do Pilodyn e IMApeso para clones de Eucalyptus, avaliados na análise conjunta entre os ambientes.

\begin{tabular}{cccc}
\hline & Volume $\left(\mathrm{m}^{3} /\right.$ ha.year $)$ & Depth $(\mathrm{mm})$ & MAIweight vol*(1/depth) \\
\hline$h^{2} g$ & $0.147 \pm 0.004$ & $0.485 \pm 0.008$ & $0.148 \pm 0.004$ \\
$h^{2} m c$ & 0.387 & 0.784 & 0.391 \\
$C^{2}{ }_{\text {int }}$ & 0.145 & 0.038 & 0.129 \\
Acgen & 0.860 & 0.982 & 0.839 \\
$H_{2 m g}$ & 0.740 & 0.964 & 0.704 \\
$r_{\text {gloc }}$ & 0.503 & 0.926 & 0.533 \\
\hline General mean & 32.845 & 18.349 & 1.790 \\
\hline CVi $(\%)$ & 17.891 & 11.795 & 19.218 \\
$C V e(\%)$ & 37.805 & 8.823 & 40.129 \\
\hline
\end{tabular}

$h^{2} g$ : Coefficients of individual heritability, free of interaction; $h^{2} m c$ : heritability of the mean of the clone; $C^{2}$ int: Coefficient of determination of the G x E interaction; Acgen: Genetic accuracy in clone selection; $r$ : Genotypic correlation between environments; General mean: General mean of traits between different environments; CVgi (\%): Coefficient of genotypic variation; $C V e$ (\%): Coefficient of experimental variation.

Revista Árvore, Viçosa-MG, v.40, n.5, p.867-876, 2016 
Table 2 - Ranking of genotypic values for variable productivity in MAIweight of the 10 best clones evaluated in the joint analysis between the environments.

Tabela 2 - Ranking of genotypic values for variable productivity in MAIweight of the 10 best clones evaluated in the joint analysis between the environments.

\begin{tabular}{|c|c|c|c|c|c|c|c|}
\hline Rank & Genotype & $\mathrm{g}$ & $\mu+g$ & Gain & New mean & $\begin{array}{l}\text { Relative gain } \\
\text { (General mean) }\end{array}$ & $\begin{array}{l}\text { Relative gain } \\
\text { (witness) }\end{array}$ \\
\hline 1 & 39659 & 1.084 & 2.867 & 1.084 & 2.867 & $60.2 \%$ & $15.49 \%$ \\
\hline 2 & 39438 & 0.909 & 2.693 & 1.014 & 2.797 & $56.3 \%$ & $12.68 \%$ \\
\hline 3 & 39095 & 0.874 & 2.658 & 0.979 & 2.762 & $54.3 \%$ & $11.27 \%$ \\
\hline 4 & 39407 & 0.874 & 2.658 & 0.944 & 2.727 & $52.4 \%$ & $9.86 \%$ \\
\hline 5 & 39410 & 0.839 & 2.623 & 0.909 & 2.693 & $50.4 \%$ & $8.45 \%$ \\
\hline 6 & 39274 & 0.839 & 2.623 & 0.909 & 2.693 & $50.4 \%$ & $8.45 \%$ \\
\hline 7 & 6808 & 0.804 & 2.623 & 0.909 & 2.693 & $50.4 \%$ & $8.45 \%$ \\
\hline 8 & 39706 & 0.804 & 2.588 & 0.874 & 2.658 & $48.5 \%$ & $7.04 \%$ \\
\hline 9 & 32949 & 0.804 & 2.588 & 0.874 & 2.658 & $48.5 \%$ & $7.04 \%$ \\
\hline 10 & 39575 & 0.769 & 2.588 & 0.874 & 2.658 & $48.5 \%$ & $7.04 \%$ \\
\hline . & . & & . & . & . & . & . \\
\hline 37 & $\begin{array}{c}32864 \\
\text { (witness) }\end{array}$ & 0.6 & 2.3 & 0.7 & 2.5 & $38.7 \%$ & - \\
\hline
\end{tabular}

values of this magnitude, it is possible to successfully select genotypes with considerable gains (MACDONALD et al., 2009).

Broadly speaking, heritability for the traits Pilodyn penetration depth $\left(h^{2} g=0.485 \pm 0.008\right)$ (Table 1) stood out for its magnitude. This is consistent with our expectations, given that quality-related traits of wood present high genetic control (SILVA, 2008). These results corroborate studies of Munieri and Raymond (2000) on genetic control of the trait Pilodyn penetration depth and basic density measured directly in progenies of Eucalyptus globulus Labill. According to these authors, the two traits showed moderate (Pilodyn penetration depth) to high genetic control (basic density).

Kube et al. (2001), also analyzing traits related to the quality of the wood in a $\mathrm{G} x \mathrm{E}$ interaction of progenies of Eucalyptus nitens (Deane and Maiden) Maiden, reported high genetic control for basic density $\left(h^{2} a=\right.$ 0.70). In addition, the authors emphasized the importance of studying traits related to technological properties of wood, as an essential factor to obtain genetic gains in the production of cellulosic pulp.

On the other hand, the heritability of wood weight $\left(h^{2} g=0.148 \pm 0.004\right)$ was moderate and similar to the heritability of the trait volume in this experiment $(0.147$ $\pm 0.004)$, which is a polygenic trait. This indicates that much of the phenotypic variability of this trait is due to environmental variation. Thus, selection based only on phenotype may be inefficient (STURION et al., 1999).

However, the $C V g i(\%)$ of MAIweight (19.218\%) was higher than that of the traits that constitute it, increasing the possibility of significant gains and making selection more accurate (Table 1). This highlights the importance of including traits related to the quality of wood in the selection of Eucalytptus clones, since G $\mathrm{x}$ E interaction studies dealing with the weight of wood are extremely scarce.

The genetic values were predicted with high accuracy, ranging from 0.839 to 0.982 . According to Resende and Duarte (2007), accuracy values between 0.70 and 0.90 are classified as high-precision values and those above 0.90 as very high precision. Thus, the experimental design and the number of replicates (30) used in the experiments were adequate to ensure the generation of reliable results with high accuracy and reliability.

With the exception Pilodyn penetration depth $(\mathrm{CVe} \%$ $=8.823 \%)$, experimental variation coefficients $(\mathrm{CVe}(\%)$; Table 1) were very high (CAGNELUTTI; STORCK, 2007). However, $\mathrm{CVe}(\%)$ is less informative than the analysis and interpretation of estimated accuracy (RESENDE; DUARTE, 2007). Resende and Duarte (2007) report that with an increased number of replicates, it is possibile to obtain high accuracy, even with high coefficients of variation.

Revista Árvore, Viçosa-MG, v.40, n.5, p.867-876, 2016 
Table 3 - Coincidence ranking of clones selected for productivity $\left(\mathrm{m}^{3} /\right.$ ha year $)$ and wood weight.

Tabela 3-Coincidence ranking of clones selected for productivity $\left(\mathrm{m}^{3} /\right.$ ha year) and wood weight.

\begin{tabular}{ccc}
\hline Rank & $\begin{array}{c}\text { Productivity } \\
\text { (volume } \mathrm{m}^{3} / \text { ha.year) }\end{array}$ & $\begin{array}{c}\text { Productivity } \\
\text { (MAIweight) }\end{array}$ \\
\hline 1 & 6808 & $\underline{6808}$ \\
2 & 6815 & $\underline{6815}$ \\
3 & 38885 & $\underline{32949}$ \\
4 & 38903 & $\underline{38903}$ \\
5 & 38904 & $\underline{39032}$ \\
6 & 38935 & $\underline{39038}$ \\
7 & 38973 & $\underline{39045}$ \\
8 & 39018 & $\underline{39095}$ \\
9 & 39030 & 39274 \\
10 & 39032 & 39352 \\
11 & 39045 & 39366 \\
12 & 39095 & $\underline{39407}$ \\
13 & 39246 & $\underline{39410}$ \\
14 & 39320 & $\underline{39416}$ \\
15 & 39407 & $\underline{39438}$ \\
16 & 39410 & 39445 \\
17 & 39416 & 39461 \\
18 & 39423 & 39498 \\
19 & 39425 & $\underline{39510}$ \\
20 & 39427 & $\underline{39569}$ \\
21 & 39438 & 39575 \\
22 & 39510 & 39596 \\
23 & 39543 & $\underline{39606}$ \\
24 & 39569 & $\underline{39654}$ \\
25 & 39606 & $\underline{39659}$ \\
26 & 39654 & $\underline{39789}$ \\
27 & 39659 & 39912 \\
28 & 39665 & 11 \\
29 & 39706 & $37 \%$ \\
30 & 39789 & \\
\hline Number of clones that do not repeat & & \\
\hline Percentage & & \\
\hline & &
\end{tabular}

The coefficient of determination of the $\mathrm{G} \times \mathrm{E}$ interaction for the trait wood weight $\left(C^{2}{ }_{i n t}=0.129\right)$ was relatively high, giving a genotypic correlation of $53.3 \%$ across the environments, which is not high, according to the classification of Resende (2002) (67\%). According to Vencovsky and Barriga (1992), low values of correlation between environments indicate the presence of complex genotype $\mathrm{x}$ environment interactions, demonstrating the need to expand $\mathrm{G} x \mathrm{E}$ interaction studies in stability and adaptability analyses for this trait.

Basic wood density, measured indirectly using Pilodyn, was the only trait evaluated that did not present a complex type of interaction, showing high correlation (RESENDE, 2002) between the environments (0.926), demonstrating that this physical feature tends to be more stable across the environments. Raymond et al. (2001) reported that because the technological properties of wood are under greater genetic control than traits such as tree growth, it can be expected that the magnitude of the $\mathrm{G} \times \mathrm{E}$ interaction for traits of growth and wood quality will be different, the latter presenting little interaction with the environment.

Thus, stability and adaptability analyses between environments can be focused on the MAIweight index, where the genetic correlation between the environments is low.

\subsection{Pairwise Genetic Correlations of environments}

Due to the high genetic correlation (RESENDE, 2002) between the Fortaleza and Cambará environments, a same group of clones can be planted in these two locations, constituting an "improvement area" as reported by Resende (2005).

On the other hand, for the other environments (São João, Capivara), separate genetic improvement programs should be established as a result of the differentiated response in the behavior of clones between these environments. This stratification into distinct improvement areas is important so that the complex interaction does not detract from genetic gains (MAIA et al., 2009; MARTINEZ et al., 2012).

Thus, despite an increase in the company's operations in order to promote 3 different areas with distinct clones (Cambará-Fortaleza, São João, Capivara), the selection of specific genotypes for each of these areas will lead to the maximization of genetic gains with the selection related to productivity in wood weight.

\subsection{Selection gains in the joint analysis free from the effect of the $G \times \mathrm{E}$ interaction}

Ranking of the 10 best clones for the trait wood weight, according to their interaction-free genotypic value (Table 2) is valid when you want to recommend clones for planting in any area, regardless of the effect of the environment. For this case, the 5 superior genotypes recommended for planting are $39659(E$. urophylla), 39438 (E. urophylla $\mathrm{x}$ E. grandis), 39095 (E. urophylla $\times$ E. grandis), 39407 (E. grandis $\times$ E. urophylla) and 39410 (E. grandis $\mathrm{x}$ E. urophylla). The gain predicted based on the mean of these 5 clones in relation to the overall experimental mean is relatively 
Table 4 - Ranking of genetic stability (MHVG), adaptability of genetic values (PRVG) and stability and adaptability simultaneously (MHPRVG), for productivity in MAIweight.

Tabela 4-Ranking of genetic stability (MHVG), adaptability of genetic values (PRVG) and stability and adaptability simultaneously (MHPRVG), for productivity in MAIweight.

\begin{tabular}{|c|c|c|c|c|c|c|c|c|}
\hline \multicolumn{3}{|c|}{ Stability } & \multicolumn{3}{|c|}{ Adaptability } & \multicolumn{3}{|c|}{ Stability and Adaptability } \\
\hline Rank & Genotype & MHVG & Genotype & PRVG & PRVG*MG & Genotype & MHPRVG & MHPRVG*MG \\
\hline 1 & 6808 & 3.64 & 39912 & 1.75 & 3.13 & 39912 & 1.746 & 3.13 \\
\hline 2 & 6815 & 3.39 & $\underline{39659}$ & 1.74 & 3.12 & $\underline{39659}$ & 1.740 & 3.11 \\
\hline 3 & 39654 & 3.15 & 6808 & 1.73 & 3.10 & 6808 & 1.732 & 3.10 \\
\hline 4 & 39420 & 3.11 & 36190 & 1.71 & 3.06 & 36190 & 1.710 & 3.06 \\
\hline 5 & 39030 & 3.01 & $\underline{39407}$ & 1.69 & 3.02 & $\underline{39407}$ & 1.684 & 3.01 \\
\hline 6 & 39407 & 2.90 & 39410 & 1.66 & 2.98 & 39410 & 1.649 & 2.95 \\
\hline 7 & 39659 & 2.90 & 6815 & 1.62 & 2.90 & 6815 & 1.621 & 2.90 \\
\hline 8 & 39416 & 2.87 & 39438 & 1.61 & 2.87 & 39438 & 1.598 & 2.86 \\
\hline 9 & 39468 & 2.80 & 39654 & 1.60 & 2.87 & 39274 & 1.587 & 2.84 \\
\hline 10 & 39425 & 2.80 & 39510 & 1.60 & 2.86 & 39654 & 1.586 & 2.84 \\
\hline . & . & . & . & . & . & . & . & . \\
\hline . & . & . & . & . & . & . & . & . \\
\hline- & 32864 & 2.38 & & 1.38 & 2.48 & & 1.367 & 2.45 \\
\hline \multicolumn{6}{|c|}{ General mean (GM) } & & & 1.79 \\
\hline \multicolumn{8}{|c|}{ Genetic gain in relation to experimental mean ( 05 best clones) } & $\%$ \\
\hline \multicolumn{9}{|c|}{ Genetic gain in relation to witness mean ( 05 best clones) } \\
\hline
\end{tabular}

Obs: Clones underlined are the five best from the ranking of predicted genotypic values, in the joint selection between environments, that are also present in the ranking for Stability, Adaptability and Stability and Adaptability $(04$ in $15,27 \%)$

high $(55 \%)$, showing that significant gains in wood weight can be obtained, if the improvement is performed in relation to the breeding population.

Since a forest improvement program implies the need to surpass the clone planted at the time, the gain for the MAIweight trait for the mean of the 5 best clones was calculated in relation to the witness ( 32864 clone) and estimated to be $12 \%$. Although the witness was ranked in the 37 th position, the gain from the 5 best clones was not significant, being less than the gain for the experimental population, which highlights the plasticity of clone 32864 and the need for new strategies of selection and genetic resources, in order to surpass the witness and obtain gains of greater than $12 \%$.

\subsection{Wood quality aggregation in the selection of superior genotypes}

In Table 3, it can be observed that there was a $37 \%$ change in MAIweight ranking, compared to the ranking for volume, demonstrating the importance of adding traits for quality of the wood to analyses for the selection process, since in this case, for each 10 clones selected for volume, 04 would not be recommended for aggregating the basic wood density trait. The importance of wood quality aggregation in the selection of Eucalyptus clones has been highlighted by several authors (NUNES et al., 2002; SANTOS et al., 2006).

According to Mitchell (1961), wood quality can be defined as the set of physical, chemical and anatomical traits that a tree or tree part possesses, allowing for the fulfillment of necessary requirements for transformation into different end products. In the pulp and paper industry, quality of the wood is characterized based on technological analyses, including: determination of fiber size, lignin content, extractive content, pulping yield and wood consumption for production of cellulose (GOMIDE et al., 2010). However, considering that these analyses are costly and time-consuming, the use of basic density, as a universal indicator of quality of wood (QUEIROZ et al., 2004; GOMIDE et al., 2010; ROSSI et al., 2014), is necessary.

Therefore, combining this physical trait of wood with volume, the criterion for growth, allows for a more accurate selection. In addition, the indirect measurement of basic density using the Pilodyn method, which is quick and reliable, makes it feasible to include a wood weight index in a standardized high-yielding production chain, which aims at maximizing gains in the production of cellulose.

Revista Árvore, Viçosa-MG, v.40, n.5, p.867-876, 2016 
According to Queiroz et al. (2004), analysis of traits related to quality of wood has shown significant interand intraspecific variations, occurring at the levels of anatomical structure, chemical composition and physical properties. Thus, inclusion of traits related to technological wood properties in the selection of superior genotypes may significantly increase the possibility of genetic gain. In addition, the non-inclusion of these traits in genetic improvement programs leads to unexpected variations in the quality of the wood, which can affect the industrial manufacturing process and, consequently, the quality of the end product (GOMIDE et al., 2010).

In this study, the final ranking for the selection of clones for commercial planting takes into account the MAIweight trait, which combines the traits of volumetric productivity per hectare and wood basic density in a single index. This index utilizing wood weight has not been previously reported in the Brazilian literature in a G x E interaction study in Eucalyptus clones.

\subsection{Stability and adaptability}

Table 4 shows that the top five clones, in relation to the criteria MHPRVG, MHVG and PRVG, do not coincide fully with the genotypic ranking predicted by the joint analysis among the environments (Table 2). The coincidence was $27 \%$ among the five best clones and there was an inversion of the order among the coinciding clones, showing that the use of these new attributes or criteria for selection provides a refinement in selection for the MAIweight trait.

Besides providing a more accurate selection, the use of the MHPRVG*MG criterion increased genetic gains. When the mean of the best 5 clones for productivity, stability and adaptability was simultaneously computed, the gain was $72 \%$ in relation to the population and $26 \%$ improvement in relation to the commercial witness (Table 4). Thus, when compared with the joint selection for productivity in MAIweight (Table 4), the selection by MHPRVG*MG provided $17 \%$ more gain with respect to the population and a $14 \%$ increase in relation to the commercial witness.

According to Neto et al. (2013), selection based on MHPRVG is crucial to direct controlled crossings, to assess the stages of the improvement program and to recommend the superior genotypes for commercial use. In addition, the adoption of these criteria is superior to selection based only on mean productivity in all environments. Thus, clones that were selected as superior only when taking into account mean productivity in all environments, were allocated in different positions in the ranking by simultaneous selection for productivity, stability and adaptability.

\section{CONCLUSION}

There is a significant $G \times E$ interaction for the trait wood weight. The creation of three units with different recommended clones was suggested to minimize the effects of the Gx E interaction (CambaráFortaleza, Capivara and São João).

Aggregating basic wood density (measured by Pilodyn) to productivity (volume), using the MAIweight trait, provided a $40 \%$ change in the ranking of the main clones, demonstrating the importance of aggregating quality of wood to the process of clonal selection and prediction of genetic gains.

Simultaneous selection for stability and adaptability (MHPRVG) increased gains in comparison to selection by genotypic values predicted in joint analysis between environments, both in relation to the breeding population and to the commercial witness. This analysis enabled the selection of 5 superior clones: 39912 (E. urophylla), 39659 (E. urophylla), 6808 (E. grandis), 36190 (E. saligna) and 39407 (E. grandis $\mathrm{x}$ E. urophylla).

\section{REFERENCES}

CAIXETA, R.P.; TRUGILHO, P.F.; ROSADO, S.C.S.; LIMA, J.T. Propriedades e classificação da madeira aplicada à seleção de genótipos de Eucalyptus. Revista Árvore, v.27, n.1, p.43-51, 2003.

CAGNELUTTI, FILHO, A.; STORCK, L. Estatísticas de avaliação da precisão experimental em ensaios de cultivares de milho. Pesquisa Agropecuária Brasileira, v.42, n.1, p.17-24, 2007.

COUTO, A.M.; TRUGILHO, P.F.; NEVES, T.A.; PROTÁSIO, T.P.; SÁ, V.A. Modeling of basic density of wood from Eucalyptus grandis and Eucalyptus urophylla using nondestructive methods. Cerne, v. 19, n.1, p.27-34, 2013. 
GOMIDE, J.L.; FANTUZZI NETO, H.; REGAZZI, A.J. Análise de critérios de qualidade da madeira de eucalipto para produção de celulose kraft. Revista Árvore, v.34, n.2, p.339-344, 2010.

GOUVÊA, A.F.G.; TRUGILHO, P.F.; GOMIDE, J.L.; SILVA, J.R.M.; ANDRADE, C.R.; ALVES, I.C.N.

Determinação da densidade básica da madeira de Eucalyptus por diferentes métodos não

destrutivos. Revista Árvore, v.35, n.2, p.349358,2011 .

GREAVES, B.L.; BORRALHO, N.M.G.; RAYMOND, C.A.; FARRINGTON, A. Use of a Pilodyn for the indirect selection of basic density in Eucalyptus nitens. Canadian Journal of Forest Research, v.26, n.9, p.1643-1650, 1996.

PINTO JÚNIOR, J.E.; STURION, J.A.; RESENDE, M.D.V.; RONZELLI JÚNIOR, P. Avaliação simultânea de produtividade, adaptabilidade e estabilidade genotípica de Eucalytpus grandis em distintos ambientes do estado de São Paulo.

Boletim de Pesquisa Florestal, n.53, p.79$108,2006$.

KUBE, P.D.; RAYMOND, C.A.; BANHAM, P.W. Genetic parameters for diameter, basic density, cellulose content and fibre properties for Eucalyptus nitens. Forest Genetics, v.8, n.4, p.285-294, 2001.

LAVORANTI, O.J.; DIAS, C.T.S.; VENCOVSKY, R. Estudo da adaptabilidade e estabilidade fenotípica de progênies de Eucalytpus grandis via metodologia AMMI. Boletim de Pesquisa Florestal, n.44, p.107-124, 2002.

LEITE, H.G. et al. Descrição e emprego de um modelo para estimar múltiplos volumes de árvores. Revista Árvore, v.19, n.1, p.75-79, 1995.

MAIA, M. C. C.; RESENDE, M. D. V.; PAIVA, J. R.; CAVALCANTI, J. J. V.; BARROS, L. M. Seleção simultânea para produção, adaptabilidade e estabilidade genotípicas em clones de cajueiro, via modelos mistos. Pesquisa Agropecuária Tropical, v.39, n.1, p.43-50, 2009.

MARTINEZ, D.T.; RESENDE, M.D.V.; COSTA, R.B.; HIGA, A.R.; SANTOS, G.A.; FIER, I.S.N. Estudo da interação genótipo $\mathrm{x}$ ambiente em progênies de Pinus taeda por meio da análise de parâmetros genéticos. Floresta, v.42, n.3, p.539$552,2012$.

MITCHELL, H.L. A concept of intrinsic wood quality, and nondestructive methods for determining quality in standing timber. Madison: Forest Products Laboratory, U. S. Department of Agriculture, 1961.

MUNIERI, A.; RAYMOND, C.A.; Genetic parameters and genotype-by-environment interactions for basic density, pilodyn penetration and stem diameter in Eucalyptus globulus. Forest Genetics, v.7, n.4, p.317328, 2000.

FARIAS NETO, J.T.; MOURA, E.F.; RESENDE, M.D.V.; CELESTINO FILHO, P.C.; AUGUSTO, S.G. Genetic parameters and simultaneous selection for root yield, adaptability and stability of cassava genotypes. Pesquisa agropecuária brasileira, v.48, n.12, p.1562-1568, 2013.

NUNES, G.H.S.; RESENDE, G.D.S.P.; RAMALHO, M.A.P.; SANTOS, J.B. Implicações da interação genótipo x ambientes na seleção de clones de eucalipto. Cerne, v.8, n.1, p.49-58, 2002.

PROTÁSIO, T.P.; GOULART, S.L.; NEVES, T.A.; TRUGILHO, P.F.; RAMALHO, F.M.G.; QUEIROZ, L.M.R.S.B. Qualidade da madeira e do carvão vegetal oriundos de floresta plantada em Minas Gerais. Pesquisa Florestal Brasileira, v.34, n.78, p.111-123, 2014.

QUEIROZ, S.C.S.; GOMIDE, J.L.; COLODETTE, J.L.; OLIVEIRA, R.C. Influência da densidade básica da madeira na qualidade da polpa kraft de clones hibrídos de Eucalyptus grandis w. Hill ex Maiden x Eucalyptus urophylla S. T. Blake. Revista Árvore, v.28, n.6, p.901-909, 2004.

RAYMOND, C.A.; SCHIMLEK, L.R.; MUNIERI, A.; MICHELL, A.J. Genetic parameters and genotype-by-environment interactions for pulp yield predicted using near infrared reflectance analysis and pulp productivity in Eucalyptus globulus. Forest Genetics, v.8, n.3, p.213224, 2001.

REIS, C.A.F.; SANTOS, P.E.T.; PALUDZYSZYN FILHO, E. Avaliação de clones de eucalipto em

Revista Árvore, Viçosa-MG, v.40, n.5, p.867-876, 2016

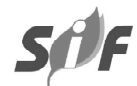


Ponta Porã, Mato Grosso do Sul. Pesquisa Florestal Brasileira, v.34, n.80, p.00-00, 2014.

RESENDE, M.D.V.; DUARTE, J.B. Precisão e controle de qualidade em experimentos de avaliação de cultivares. Pesquisa

Agropecuária Tropical, v.37, n.3, p.182-194, 2007.

RESENDE, M.D.V. Novas abordagens estatísticas na análise de experimentos e campo. Colombo: Embrapa Florestas, 2004. 60p. (Documentos, 100).

\section{RESENDE, M.D.V. Genética biométrica e} estatística no melhoramento de plantas perenes. Brasília: Embrapa informações tecnológicas, 2002.975p.

RESENDE, M.D.V. Melhoramento de Essências Florestais. In: BORÉM, A. Melhoramento de Espécies Cultivadas. Viçosa, MG: UFV, 2005. p.717-780.

ROCHA, R.B. Avaliação do método centróide para estudo da adaptabilidade ao ambiente de clones de Eucalyptus grandis. Ciência Florestal, v. 15, n. 3, p. $255-266,2005$.

ROSADO, A.M. Seleção simultânea de clones de eucalipto de acordo com produtividade, estabilidade e adaptabilidade. Pesquisa Agropecuária Brasileira, v.47, n.7, p.964$971,2012$.
ROSSI, S.; CAIRO, E.; KRAUSE, C.;

DESLAURIERS, A. Growth and basic wood properties of black spruce along an alti-latitudinal gradient in Quebec, Canada [online]. Annals of Forest Science. (Publicado on line em 10 de julho de 2014).

SANTOS, G.A.; XAVIER, A.; LEITE, H.G. Desempenho silvicultural de clones de Eucalyptus grandis em relação às árvores matrizes. Revista Árvore, v.30, n.5, p.737-747. 2006.

SANTOS, G.A.; RESENDE, M.D.V.; SILVA, L.D.; HIGA, A.; ASSIS, T.F. Adaptabilidade de híbridos multiespécies de Eucalyptus ao Estado do Rio Grande do Sul. Revista Árvore, v.37, n.4, p.759-769, 2013.

SILVA, L.D. Melhoramento genético de Eucalyptus benthamii Maiden et Cambage visando a produção de madeira serrada em áreas de ocorrência de geadas severas. 2008. 275f. Tese (Doutorado em Engenharia Florestal) - Universidade Federal do Paraná, Curitiba, 2008.

STURION, J.A.; RESENDE, M.D.V.; CARPANEZZI, A.A. Controle genético e estimativa de ganho genético para peso de massa foliar em erva-mate (Ilex paraguariensis St. Hil.). Boletim de Pesquisa Florestal, n.38, p.5-12, 1999.

VENCOVSKY, R.; BARRIGA, P. Genética biométrica no fitomelhoramento. Ribeirão Preto: Sociedade Brasileira de Genética, 1992. 486p. 